\title{
INFLUENCE OF A PROTEIN SYNTHESIS INHIBITOR FROM BARLEY SEEDS UPON DIFFERENT STEPS OF ANIMAL CELL-FREE PROTEIN SYNTHESIS
}

\author{
by \\ KATSUHIKO ASANO ${ }^{1.31}$, BIRTE SVENSSON ${ }^{11}$, FLEMMING M. POULSEN ${ }^{11}$, \\ ODD NYGÄRD ${ }^{2)}$ and LARS NILSSON ${ }^{2)}$
}

1) Department of Chemistry, Carlsberg Laboratory, Gamle Carlsberg Vej 10, DK-2500 Copenhagen Valby, to whom correspondence should be addressed

2) Department of Cell Biology, Wenner-Grens Institute, University of Stockholm, S-106 91 Stockholm

3) Present address: Applied Bioscience Laboratory, Kirin Brewery Co., Ltd., 2-2, Soujamachi 1 chome, Maebashi-shi, 371 Japan

Keywords: Initiation, elongation, puromycin reaction, antibiotics

\begin{abstract}
The mechanism of action on animal cell-free protein synthesis by the translation inhibitor II from barley seeds has been studied using the rabbit reticulocyte lysate protein synthesis system. No influence was detected on the ribosomal binding of initiator-tRNA, Met-tRNA, in the presence of barley hordein mRNA, or on the aminoacyl-tRNA synthetase catalyzed formation of aminoacyl-tRNA, suggesting the inhibitor to be without effect both on the protein synthesis initiation and on the supply of aminoacyl-tRNAs. Inhibition of reactions in the elongation cycle was examined by measurement of the transfer of the nascent peptide from peptidyl-tRNA to puromycin. The observed lack of influence on the puromycin reaction implies that the barley inhibitor neither blocked the peptidyltransferase nor the translocation activities. In addition, the high amount of Phe-tRNA bound to ribosomes in the presence of inhibitor and poly(U) suggested the aminoacyl-tRNA binding step to be unaffected by the inhibitor. These findings are compatible with inhibition of a reaction in the elongation cycle subsequent to the aminoacyl-tRNA binding but preceding the translocation.
\end{abstract}

\section{INTRODUCTION}

Three closely related inhibitors of animal cell-free protein synthesis have been purified from barley seeds (1). The amino acid sequence of the predominant form, barley translation inhibitor II, has recently been determined (2) and found to be homologous with the A-chain of ricin from castor bean (12). Related proteins have been isolated from a wide variety of plants $(3,23,24,27)$ and extensive studies of structure and function have been performed for pokeweed antiviral proteins (PAP) and ricin (4, 5, 7, 10-13,

Abbreviations: $\mathrm{EF}=$ elongation factor; $\mathrm{ID}_{50}=$ inhibitor concentration causing $50 \%$ inhibition of the in vitro translation; NEM = N-ethylmaleimide; $\mathrm{PAP}=$ pokeweed antiviral protein; $\operatorname{poly}(\mathrm{U})=$ polyuridylic acid; Tricine = $\mathrm{N}$-[(2-hydroxy-1,1-bis (hydroxymethyl)ethyl]glycine; Tris = 2-amino-2-hydroxymethylpropane-1,3-diol. 
21, 24-26). The barley proteins are less effective inhibitors than the ricin A-chain or PAP $(1,3$, 23). The target reaction has only been identified for a few of this class of protein synthesis inhibitors. Therefore, in the present study we investigated the mode of action of the barley inhibitor II by testing for its effects on individual reactions of the in vitro translation, i.e. MettRNA $_{f}$ binding in the initiation phase and peptidyltransferase reaction, translocation and ribosomal binding of aminoacyl-tRNA of the elongation step, using rabbit reticulate lysates.

\section{MATERIALS AND METHODS}

\subsection{Materials}

Barley translation inhibitor II (1) and barley hordein mRNA $(6,17)$ were prepared as described. An aminoacyl-tRNA synthetase preparation from stroma of barley plastids (19) was generously supplied by Dr. C. GAMINI KaNNANGARA, Department of Physiology, Carlsberg Laboratory.

mRNA-dependent rabbit reticulocyte lysate (both depleted and not depleted with respect to endogenous amino acids, ribosome concentration approx. $\left.270 \mathrm{pmol} \times \mathrm{ml}^{-1}(22)\right)$ was from Amersham International, Amersham, U.K.; L$\left[{ }^{35} \mathrm{~S}\right]$-methionine, L- $\left[{ }^{14} \mathrm{C}\right]-$ and L- $\left[{ }^{3} \mathrm{H}\right]$-phenylalanine from New England Nuclear Chemicals, Dreieich, F.R.G.; tRNA of calf liver from Boehringer Mannheim, Mannheim, F.R.G.; tRNA $^{\text {Phe }}$ of brewers yeast, RNA of Torula yeast, poly(U), anisomycin, cycloheximide and N-ethylmaleimide from Sigma Chemical Co., St. Louis, MO; aurintricarboxylic acid (ammonium salt) and cetyltrimethylammonium bromide from $\mathrm{E}$. Merck, Darmstadt, F.R.G.; glass fiber filter (GF/ C) from Whatman, Maidstone, U.K.; nitrocellulose filter (HAWP) from Millipore, Molsheim, France. All other chemicals were of analytical grade.

\subsection{Methods}

\subsubsection{Binding of initiator-tRNA to ribosomes}

Amino acid-depleted rabbit reticulocyte lysate $(15 \mu \mathrm{l})$ was preincubated in the presence or absence of various inhibitors (18) of protein synthesis at $30^{\circ} \mathrm{C}$ for $15 \mathrm{~min}$. The lysate was then incubated in a $20 \mu \mathrm{l}$-reaction mixture containing
$0.44 \mu \mathrm{M}-\mathrm{L}-\left(35_{\mathrm{s}}\right)-$ methionine $(10 \mu \mathrm{Ci})$ and barley hordein mRNA $\left(\mathrm{A}_{260}=11.0,2 \mu \mathrm{l}\right)$ at $30^{\circ} \mathrm{C}$ for 30 $\mathrm{min}$. The reaction was stopped by adding $1 \mathrm{ml}$ of ice-cold $50 \mathrm{mM}$-Tris- $\mathrm{HCl}$ pH 7.4 containing 60 $\mathrm{mM}-\mathrm{KCl}$ and $6 \mathrm{~mm}-\mathrm{MgCl}_{2}(10)$. The mixture was then filtered on a nitrocellulose filter and after ten washings with $1 \mathrm{ml}$ portions of the ice-cold buffer, the radioactivity of the retained ribosomes was measured.

\subsubsection{Met-and Phe-tRNA synthesis}

tRNA of calf liver $(40 \mu \mathrm{g})$ and aminoacyltRNA synthetase $(100 \mu \mathrm{g})$ were incubated, in the presence or absence of translation inhibitor, in $240 \mu \mathrm{l}$ of $77 \mathrm{mM}$-Tricine $\mathrm{pH} 6.8$ containing 2.8 $\mathrm{mM}-\mathrm{MgCl}_{2}$ at $30{ }^{\circ} \mathrm{C}$ for $15 \mathrm{~min}$. Then 0.01 $\mu \mathrm{M}-\mathrm{L}-\left(35_{\mathrm{s}}\right)$-methionine $(3 \mu \mathrm{Ci})$ and $1 \mathrm{mM}-\mathrm{ATP}$ were added and the reaction mixture was incubated at $30^{\circ} \mathrm{C}$ for $30 \mathrm{~min}$. Essentially the same procedure was used with $\mathrm{tRNA}^{\text {Phe }}(12 \mu \mathrm{g})$ and $0.58 \mu \mathrm{M}-\mathrm{L}-\left[{ }^{3} \mathrm{H}\right]-$ phenylalanine $(12 \mu \mathrm{Ci})$. The reaction was stopped by adding $10 \mu \mathrm{l}$ of $50 \%$ trichloroacetic acid. The mixture was filtered on a glass fiber filter and after washing with three 5 $\mathrm{ml}$ portions of cold $5 \%$ trichloroacetic acid, the radioactivity of the retained aminoacyl-tRNA was measured.

\subsubsection{In vitro translation systems}

Rabbit reticulocyte lysate $(55 \mu \mathrm{l})$ was incubated in a $70 \mu \mathrm{l}$ reaction mixture containing 0.63 $\mu \mathrm{M}-\mathrm{L}-\left(35_{\mathrm{S}}\right)$-methionine $(50 \mu \mathrm{Ci})$ and barley hordein mRNA $\left(\mathrm{A}_{260}=11.0,5 \mu \mathrm{l}\right)$ at $30^{\circ} \mathrm{C}$. For poly(U) directed polyphenylalanine synthesis, amino acid depleted rabbit reticulocyte lysate $(15 \mu \mathrm{l})$ was incubated in a $30 \mu \mathrm{l}$ reaction mixture containing $119 \mu \mathrm{M}-\mathrm{L}-\left[{ }^{14} \mathrm{C}\right]$-phenylalanine (1.6 $\mu \mathrm{Ci}), 33 \mu \mathrm{M}$-non-radioactive amino acids (omitting L-phenylalanine), $67 \mathrm{mM}$-potassium acetate, $3.3 \mathrm{~mm}$-magnesium acetate, $1.7 \mathrm{~mm}$ ATP, $10 \mu \mathrm{g}$ of $\mathrm{t}-\mathrm{RNA}^{\text {Phe }}$, aminoacyl-tRNA synthetase $(100 \mu \mathrm{g})$ and $20 \mu \mathrm{g}$ of poly $(\mathrm{U})$ at $30^{\circ} \mathrm{C}$ for $30 \mathrm{~min}$. The incorporated radioactivity was measured on $10 \mu$ laliqouts as described in 2.2.4.

\subsubsection{Analysis of the puromycin reaction}

The amount of peptidyl-tRNA was measured essentially as reported (16). Puromycin was 
added to the translation mixtures as described in Figure 1. In order to precipitate peptidyl-tRNA, aliquots of translation mix ture $(5 \mu$, see section 2.2.3) were added $1 \mathrm{ml}$ of $2 \%$ cetyltrimethylammonium bromide followed by $1 \mathrm{ml}$ of 0.5 M-sodium acetate $\mathrm{pH} 5.4$ containing 0.5 mg $\mathrm{ml}^{-1}$ of yeast RNA as carrier. After $30 \mathrm{~min}$, the precipitates were collected on glass fiber filters and washed thoroughly with water. The filters were then boiled in $10 \%$ trichloroacetic acid for $10 \mathrm{~min}$ to remove aminoacyl-tRNA, washed with three $5 \mathrm{ml}$ portions of $5 \%$ cold trichloroacetic acid and dried. The radioactivity retained on the filters was measured.

\subsubsection{Inhibition of translation by $\mathrm{N}$ - ethylmaleimide}

Amino acid depleted rabbit reticulocyte lysate was treated with $10 \mathrm{mM}-\mathrm{N}$-ethylmaleimide at 0 ${ }^{\circ} \mathrm{C}$ for $10 \mathrm{~min}$ (15). Remaining $\mathrm{N}$-ethylmaleimide was reacted with $20 \mathrm{mM}$-mercaptoethanol and the lysate was checked for the loss of ability to synthesize polyphenylalanine using the conditions given in 2.2.3.

\subsubsection{Phe-tRNA binding to ribosomes}

Amino acid depleted, NEM-treated rabbit reticulocyte lysate $(30 \mu \mathrm{l})$ (see 2.2 .5$)$ was preincubated with translation inhibitor ( $20 \mathrm{ng}$ ) at 30 ${ }^{\circ} \mathrm{C}$ for $15 \mathrm{~min}$ and subsequently incubated at 30 ${ }^{\circ} \mathrm{C}$ for $30 \mathrm{~min}$ under the conditions given for poly(U) directed polyphenylalanine synthesis (see 2.2.3). The reaction was stopped and the radioactivity associated to ribosomes was measured (see 2.2.1).

\subsubsection{Analytical procedures}

Concentrations of barley translation inhibitor II in stock solutions were determined by amino acid analysis (1). Radioactivity was measured in a Beckman LS 3155 T liquid scintillation counter.

\section{RESULTS AND DISCUSSION}

\subsection{Met-tRNA $A_{f}$ ribosomal binding in the presence of inhibitor}

Protein synthesis in eukaryotes is initiated by the binding of Met-tRNA $A_{i}$ to the 40 S ribosomal subunit, followed by the association with mRNA and the $60 \mathrm{~S}$ ribosomal subunit. The effect of the translation inhibitor on the binding of the initiator-tRNA to ribosomes was examined using amino acid depleted rabbit reticulocyte lysate in the presence of radioactive methionine. Like ricin and PAP (3) the barley inhibitor did not reduce the binding of MettRNA $_{\mathrm{f}}$ (Table I), in contrast to the inhibitor of protein synthesis initiation, aurintricarboxylic acid (18), employed as a control (Table I). Furthermore, to eliminate the possibility that the inhibition of translation could stem from lack of activated amino acids, aminoacyl-tRNA synthetase catalyzed formation of Met- and Phe-tRNA was examined. Apparently the yields of aminoacyl-tRNAs were unaffected by the presence of inhibitor (Table II), thus the supply of aminoacyl-tRNAs was assumed to be sufficient for efficient translation to take place.

Table 1. The effect of the barley translation inhibitor on the initiation step of protein synthesis.

\begin{tabular}{|c|c|c|}
\hline \multirow[b]{2}{*}{ Inhibitor added } & \multicolumn{2}{|c|}{ Binding of methionyl-tRNA } \\
\hline & $\begin{array}{l}\text { Radioactivity incorporated } \\
\left(\mathrm{cpm} \cdot 10^{-3}\right)\end{array}$ & $\%$ control \\
\hline Translation inhibitor $(16 \mathrm{nM})^{\mathrm{a})}$ & 217 & 107 \\
\hline Aurintricarboxylic acid (10 mM) & 76 & 37 \\
\hline None & 203 & 100 \\
\hline
\end{tabular}

a) Approx. 20 times as high a concentration as $\operatorname{ID}_{50}$ (1). See 2.2 .1 for further details. 
Table II. Synthesis of aminoacyl-tRNA in the presence of barley translation inhibitor.

\begin{tabular}{lll} 
& \multicolumn{3}{c}{$\begin{array}{c}\text { Radioactivity incorporated } \\
\left(\mathrm{cpm} \cdot 10^{-3}\right)\end{array}$} \\
\cline { 2 - 3 } Translation inhibitor $(\mathrm{nM})$ & Met-tRNA & Phe-tRNA \\
\hline $33^{\text {al }}$ & 120 & - \\
$330^{\text {bt }}$ & - & 7 \\
None & 120 & 7 \\
\hline
\end{tabular}

a) Approx. 40 times the $\mathrm{ID}_{50}$ for in vitro tranlation of barley hordein mRNA (1).

b) Approx. 33 times the $\mathrm{ID}_{\mathrm{s} 0}$ for the poly(U) directed polyphenylalanine synthesis.

See 2.2.2 for further details.

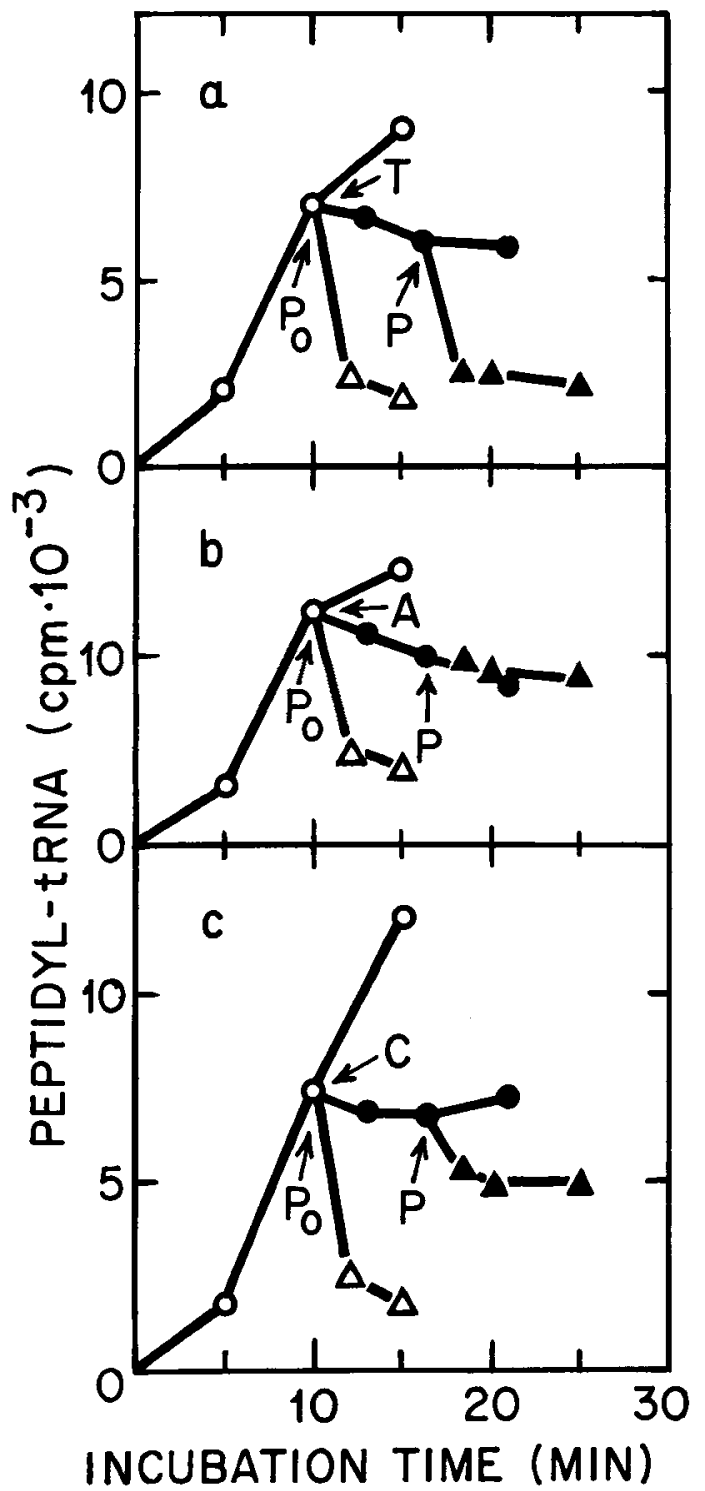

\subsection{Peptidyl transfer to puromycin after inhibitor treatment}

Puromycin, an analogue of the 3-end of aminoacyl-tRNA, binds at or near the ribosomal A-site and accepts the peptidyl moiety of peptidyl-tRNA located in the P-site to form peptidylpuromycin which is subsequently released from the ribosome (28). This reaction is specific for P-site located peptidyl-tRNA at normal salt concentrations and has previously been utilized to classify antibiotics with respect to target reaction in the elongation cycle. In the present study the puromycin reaction was used to test if the barley inhibitor interfered with the translocation or the peptidyltransferase reactions (Fi-

Figure 1. The effect of the translation inhibitor on the puromycin reaction. In vitro translation reaction mixture containing barley hordein mRNA $(70 \mu \mathrm{l})$ (see 2.2.3) was incubated for ten minutes. Then $0.2 \mathrm{~mm}$ puromycin $\left(\mathrm{P}_{\mathrm{o}}\right)$ was added to a $15 \mu \mathrm{l}$ portion of the reaction mixture and a) $3.6 \mu \mathrm{M}$-barley translation inhibitor (T), b) $1 \mathrm{~mm}$-anisomycin (A) or c) 0.9 mM-cycloheximide (C) was added to a portion $40 \mu \mathrm{l}$ of the same reaction mixture. After $15 \mathrm{~min}$ of incubation, $0.2 \mathrm{mM}$-puromycin $(\mathrm{P})$ was added to a $20 \mu \mathrm{l}$ portions of the reaction mixtures a-c. Aliquots $5 \mu \mathrm{l}$ were removed with the indicated time intervals and the content of peptidyl-tRNA was measured as described in section 2.2.4. The symbols correspond to the noninhibited rabbit reticulocyte lysate system $(O)$, the system inhibited by the barley translation inhibitor, anisomycin or cycloheximide $(\bullet)$, the puromycin-treated noninhibited system $(\Delta)$ and the puromycin-treated system inhibited by either of the three inhibitors $(\Delta)$. 
Table III. Inhibition of polyphenylalanine synthesis by NEM.

\begin{tabular}{|c|c|c|}
\hline \multirow[b]{3}{*}{ Inhibitor added } & \multicolumn{2}{|c|}{ Polyphenylalanine synthesis } \\
\hline & Phenylalanine incorporated & $\%$ inhibition \\
\hline & approx. pmol & \\
\hline None & 43 & 0 \\
\hline N-ethylmaleimide & 3 & 93 \\
\hline
\end{tabular}

Rabbit reticulocyte lysate ( $15 \mu \mathrm{l}, 4 \mathrm{pmol}$ ribosomes) depleted of all amino acids was treated with NEM (see 2.2.5). Before and after this inactivation the polyphenylalanine synthesis of the lysate was assayed (see 2.2.3).

gure 1a). In control experiments we confirmed the function of two well-characterized antibiotics, cycloheximide and anisomycin $(16,18)$. In the presence of anisomycin, the puromycin reaction was completely inhibited due to a blocked peptidyltransferase reaction (Figure 1b). The translocation arrest caused by cycloheximide resulted in a partial inhibition of the puromycin reaction due to inability of A-site located peptidyl-tRNA to be transferred to the puromycin sensitive $\mathrm{P}$-site (Figure $1 \mathrm{c}$ ). As seen in Figure la the barley inhibitor was without effect on the puromycin reaction, even at a concentration of 4500 times the $\mathrm{ID}_{50}$, which suggests that it blocks neither the peptidyltransferease reaction nor the translocation. In contrast, ricin A-chain and PAP are both thought to inhibit the translocation $(13,26)$. This behaviour of the barley inhibitor resembles that of the mold translation inhibitor $\alpha$-sarcin, but $\alpha$-sarcin specifically cleaves a single phosphodiester bond in 28S ribosomal RNA (9), while the barley inhibitor has no ribonuclease activity (1). It is obvious, therefore, that the mode of action of the barley inhibitor differs from those previously characterized for plant and mold translation inhibitors.

\subsection{Ribosomal binding of Phe-tRNA in the presence of inhibitor}

In order to study the isolated event of poly(U) directed ribosomal binding of Phe-tRNA in the reticulocyte system, we destroyed the activity of EF-2 by NEM-treatment (15). The extent of Phe-tRNA binding at the ribosomal A-site was then measured in the presence of barley translation inhibitor employing the NEM-treated reticulocyte lysate. Although the NEM-treatment efficiently prevented incorporation of labelled phenylalanine into the hot-acid insoluble material (Table III), a small fraction of the EF-2

Table IV. The effect of the translation inhibitor on the binding of Phe-tRNA to NEM-treated ribosomes.

\begin{tabular}{|c|c|c|}
\hline \multirow[b]{3}{*}{ Inhibitor added } & \multicolumn{2}{|c|}{ Binding of Phe-tRNA } \\
\hline & Phenylalanine incorporated & $\%$ control \\
\hline & approx. pmol & \\
\hline None & 63 & 100 \\
\hline Translation inhibitor & 3 & 5 \\
\hline
\end{tabular}

NEM-inhibited lysate as described in Table III ( $30 \mu \mathrm{l}, 8 \mathrm{pmol}$ ribosomes) was preincubated with $20 \mathrm{ng}$ of the translation inhibitor at $30^{\circ} \mathrm{C}$ for $15 \mathrm{~min}$, and then further incubated at $30^{\circ} \mathrm{C}$ for $30 \mathrm{~min}$ under the condition employed for translation of poly(U) (see 2.2.3). The reaction was stopped (see 2.2.1) and the radioactivity associated with the ribosomes retained on the filter was measured. 
remained active allowing the synthesis of short oligopeptides on the poly(U) programmed ribosomes (Table IV). Preincubation of the NEMtreated lysates with $21 \mathrm{nM}$ translation inhibitor $\left(\mathrm{ID}_{50}\right.$ for polyphenylalanine synthesis is $10 \mathrm{nM}$ ) reduced the amount of labelled phenylalanine associated with ribosomes to a level corresponding to a molar ratio of 0.4 Phe-tRNA to ribosome (Table IV). A similar value and lower values were previously reported for Phe-tRNA binding to untreated, poly(U) programmed ribosomes $(8,14,20)$. Thus, the inhibitor seemed not to influence the Phe-tRNA binding, but stopped the residual translation in the NEM-treated lysate, as expected.

\section{CONCLUSION}

The present study concerns the mode of inhibition of in vitro animal protein synthesis by the translation inhibitor II from barley seeds. This inhibitor has apparently no effect on the initiation phase and the aminoacyl-tRNA binding, peptidisation and translocation of the elongation phase, thus the mode of action is indirectly demonstrated to differ from that of the other structurally related translation inhibitors. A target reaction of the barley translation inhibitor still remains to be identified, but it seems possible that the translation is arrested at a partial reaction of the elongation cycle between the aminoacyl-tRNA binding and the translocation. Due to the complexity of the reticulocyte lysate protein synthesis system, studies of an individual reaction in the elongation impose great experimental difficulties, and it was decided, therefore, to investigate further the mode of action of the barley inhibitor in reconstituted systems for protein synthesis (22).

\section{ACKNOWLEDGMENTS}

We are indebted to Professor MARTIN OTTESEN for his continuous encouragement and advice as well as for his critical reading of the manuscript. We wish to thank Dr. ANDERS BRANDT for valuable discussions throughout this work and Dr. C. GAMINI KANNANGARA for providing the aminoacyl-tRNA synthetase and for help with the aminoacyl-tRNA synthesis assay. K. ASANO was on leave from Kirin Brewery Co., Ltd., Tokyo, Japan and acknowledges their financial support.

\section{REFERENCES}

1. Asano, K., B. Svensson \& F. M. Poulsen: Isolation and characterization of inhibitors of animal cell-free protein synthesis from barley seeds. Carlsberg Res. Commun. 49, 619-626 (1984)

2. Asano, K., I. Svendsen, F. M. Poulsen \& B. SVENSSON: A protein synthesis inhibitor from barley seeds showing a distant homology with the ricin A chain. 13th International Congress of Biochemistry, Amsterdam August 1985, abstract FR-142

3. BARBIERI, L. \& F. STIRPE: Ribosome-inactivating proteins from plants: Properties and possible uses. Cancer Surveys 1, 489-520 (1982)

4. Benson, S., S. Olsnes \& A. Pihl: On the mechanism of protein-synthesis inhibition by abrin and ricin. Eur. J. Biochem. 59, 573-580 (1975)

5. BJorn, M. J., J. Larrick, M. Piatak \& K. J. WilSON: Characterization of translational inhibitors from Phytolacca americana, amino-terminal sequence determination and antibody-inhibitor conjugates. Biochim. Biophys. Acta 790, 154-163 (1984)

6. BRANDT, A. \& J. INGVERSEN: Isolation and translation of hordein messenger RNA from wild type and mutant endosperms in barley. Carlsberg Res. Commun. 43, 451-469 (1978)

7. Carrasco, L., C. Fernandez-Puentes \& D. VazQUEZ: Effects of ricin on the ribosomal sites involved in the interaction of the elongation factors. Eur. J. Biochem. 54, 499-503 (1975)

8. Da Costa.Carvalho, M. G., J. F. Carvalho \& W. MERRICK: Biological characterization of various forms of elongation factor 1 from rabbit reticulocytes. Arch. Biochem. Biophys. 234, 603611 (1984)

9. ENDO, Y. \& I. G. WoOL: The site of action of $\alpha$-sarcin on eurokaryotic ribosomes. J. Biol. Chem. 257, 9054-9060 (1982)

10. Fernandez-Puentes, C., L.Carrasco \& D. VazQUEZ: Site of action of ricin on the ribosome. Biochemistry 15, 4364-4369 (1976)

11. Fernandez-Puentes, C. \& D. VazQuez: Effects of some proteins that inactivate the eukaryotic ribosome. FEBS Lett. 78, 143-146 (1977)

12. Funatsu, G., S. Yoshitake \& M. Funatsu: Primary structure of lle chain of ricin D. Agric. Biol. Chem. 42, 501-503 (1978) 
13. GESSNER, S. L. \& J. D. IR VIN: Inhibition of elongation factor 2-dependent translocation by the pokeweed antiviral protein and ricin. J. Biol. Chem. 255, 3251-3253 (1980)

14. Grasmuk, H., R. D. Nolan \& J. DRews: Elongation factor 1 from Ascites tumor cells: Interaction with ribosomes and elongation factor 2 . Eur. $\mathbf{J}$. Biochem. 48, 485-493 (1974)

15. HaRdeSTY, B., W. MCKeENHAN \& W. CulP: Aminoacyl transfer RNA binding enzyme (T-I) from rabbit reticulocytes. Meth. Enzymol. 20, 316-330 (1971)

16. Hobden, A. N. \& E. CUNDliffe: The mode of action of alpha sarcin and a novel assay of the puromycin reaction. Biochem. J. 170, 57-61 (1978)

17. HopP, H. E., S. K. Rasmussen \& A. BRandT: Organization and transcription of $B 1$ hordein genes in high lysine mutants barley. Carlsberg Res. Commun. 48, 201-216 (1983)

18. JIMENEZ, A.: Inhibitors of translation. Trends Biochem. Sci. 1, 28-30 (1976)

19. Kannangara, C. G., S. P. Gough, R. P. Oliver \& S. K. RasmuSSEN: Biosynthesis of $\Delta$-aminolevulinate in greening barley leaves VI. Activation of glutamate by ligation to RNA. Carlsberg Res. Commun. 49, 417-437 (1984)

20. Lauer, S. J., E. Burks. J. D. Irwin \& J. M. Ravel: Purification and characterization of three elongation factors, EF-1 $\alpha, \mathrm{EF}-1 \beta \gamma$, and $\mathrm{EF}-2$ from wheat germ. J. Biol. Chem. 259, 1644-1648 (1984)

21. MacConnelL, W. P., D. W. Eurman \& N. O. KAPLAN: The action of ricin A-chain on ribosomes. Biochem. Biophys. Res. Commun. 108, 809-814 (1982)

Accepted by H. KLENOW
22. Nilsson, L., K. asano, B. Svensson, F. M. PoulSEN \& O. NYGARD: Reduced turnover of the elongation factor EF-1'ribosome complex after treatment with the protein synthesis inhibitor II from barley seeds. (manuscript in preparation)

23. Olsnes, S. \& A. Pihl: Toxic lectins and related proteins. In: Molecular Action of Toxins and Viruses. Cohen and van Heyningen eds., Elsevier, 51-105 (1982)

24. Ready, M. P., R. P. Adams \& J. D. Robertus: Dodecandrin, a new ribosome- inactivating protein from Phytolacca dodecandra. Biochim. Biophys. Acta 791, 314-319 (1984)

25. REAdy, M., K. WiLson, M. PiataK \& I. D. ROBERTUS: Ricin-like plant toxins are evolutionarily related to single-chain ribosome-inactivating proteins from Phytolacca. J. Biol. Chem. 259, 15252 15256 (1984)

26. SPERTI, S. \& L. MONTANARO: Ricin and modeccin do not inhibit the elongation factor 1-dependent binding of aminoacyl-tRNA to ribosomes. Biochem. J. 178, 233-236 (1979)

27. Stirpe, F., A. Gasperi-Campani, L. Barnieri. A. Falasca, A. Abbondanza \& W. A. Stevens: Ribosome-inactivating proteins from the seeds of Saponaria officinalis L. (soapwort), of Agrostemma githago L. (corn cockle) and of Asparagus officinalis $\mathrm{L}$. (asparagus), and from the latex of Hura crepirtans L. (sandbox tree). Biochem. J. 216, 617-625 (1983)

28. Traut, R. R. \& R. E. Monro: The puromycin reaction and its relation to protein synthesis. $J$. Mol. Biol. 10, 63-72 (1964) 